\title{
VALIDATION OF FULL CORE GEOMETRY MODEL OF THE NODAL3 CODE IN THE PWR TRANSIENT BENCHMARK PROBLEMS
}

\author{
T.M. Sembiring ${ }^{1}$, S. Pinem ${ }^{1}$, P.H. Liem ${ }^{2}$ \\ ${ }^{1}$ Center for Nuclear Reactor Technology and Safety, National Nuclear Energy Agency of Indonesia \\ (BATAN), Kawasan PUSPIPTEK Gd. No. 80 Serpong, Tangerang Selatan, INDONESIA 15310 \\ ${ }^{2}$ Nippon Advanced Information Service (NAIS Co. Inc.), 416 Muramatsu, Tokaimura, Ibaraki, Japan 319-112 \\ Email: tagorms@batan.go.id \\ Diterima editor: 20 Agustus 2015 \\ Direvisi editor: 1 September 2015 \\ Disetujui untuk publikasi: 15 September 2015
}

\begin{abstract}
VALIDATION OF FULL CORE GEOMETRY MODEL OF THE NODAL3 CODE IN THE PWR TRANSIENT BENCHMARK PROBLEMS. The coupled neutronic and thermal-hydraulic $(\mathrm{T} / \mathrm{H}) \mathrm{code}$, NODAL3 code, has been validated in some PWR static benchmark and the NEACRP PWR transient benchmark cases. However, the NODAL3 code have not yet validated in the transient benchmark cases of a control rod assembly (CR) ejection at peripheral core using a full core geometry model, the $\mathrm{C} 1$ and $\mathrm{C} 2$ cases. By this research work, the accuracy of the NODAL3 code for one CR ejection or the unsymmetrical group of CRs ejection case can be validated. The calculations by the NODAL3 code have been carried out by the adiabatic method (AM) and the improved quasistatic method (IQS). All calculated transient parameters by the NODAL3 code were compared with the reference results by the PANTHER code. The maximum relative difference of $16 \%$ occurs in the calculated time of power maximum parameter by using the IQS method, while the relative difference of the AM method is $4 \%$ for $\mathrm{C} 2$ case. All calculation results by the NODAL3 code shows there is no systematic difference, it means the neutronic and $\mathrm{T} / \mathrm{H}$ modules are adopted in the code are considered correct. Therefore, all calculation results by using the NODAL3 code are very good agreement with the reference results.
\end{abstract}

Keywords: nodal method, coupled neutronic and thermal-hydraulic code, PWR, transient case, control rod ejection.

\begin{abstract}
ABSTRAK
VALIDASI MODEL GEOMETRI TERAS PENUH PAKET PROGRAM NODAL3 DALAM PROBLEM BENCHMARK GAYUT WAKTU PWR. Paket program kopel neutronik dan termohidraulika $(T / H)$, NODAL3, telah divalidasi dengan beberapa kasus benchmark statis PWR dan kasus benchmark gayut waktu PWR NEACRP. Akan tetapi, paket program NODAL3 belum divalidasi dalam kasus benchmark gayut waktu akibat penarikan sebuah perangkat batang kendali $(C R)$ di tepi teras menggunakan model geometri teras penuh, yaitu kasus C1 dan C2. Dengan penelitian ini, akurasi paket program NODAL3 untuk kasus penarikan sebuah CR atau sekelompok CR yang tidak-simetris dapat divalidasi. Perhitungan paket program NODAL3 dilakukan dengan metode adiabatic (AM) dan improved quasistatic (IQS). Seluruh parameter gayut waktu hasil perhitungan paket program NODAL3 dibandingkan dengan hasil acuan dengan paket program PANTHER. Perbedaan relatif maksimum sebesar $16 \%$ terjadi dalam perhitungan parameter waktu daya maksimum dengan metode IQS pada kasus C2, sedangkan perbedaan relatif dengan metode AM adalah 4\%. Seluruh hasil perhitungan dengan paket program NODAL3 menunjukkan tidak adanya perbedaan yang sistematis, berarti modul neutronik dan T/H yang diadopsi di NODAL3 sudah benar. Oleh karena itu, seluruh perhitungan dengan paket program NODAL3 sangat sesuai dengan hasil acuan.
\end{abstract}

Kata kunci: metode nodal, paket program kopel neutonik dan termo-hidrolika, kasus gayut-waktu, tertariknya batang kendali. 


\section{INTRODUCTION}

A control rod or group rod ejection accident (REA) is one of causes of reactivity insertion accident (RIA) in the Pressurized Water Reactor (PWR). When REA is taken place, there is a potential for fuel rod damage due to insufficient of heat removal as a consequent of fuel temperature rise. Therefore, the transient behaviour of reactivity, power and temperature during the REA is very important to be analyzed to guarantee the fuel rod integrity. The REA is categorized as an anticipated operational occurrence (AOO) or in severe cases as a postulated accident.

Some previous research works showed that the analytical tool for analyzing the transient behaviour of a REA is the coupled neutronic thermal-hydraulic codes [1-7]. BATAN, as a research institute, has developed a coupled neutronic thermal-hydraulic $(\mathrm{T} / \mathrm{H})$ code, NODAL3, based on the nodal multi-group neutron diffusion method with 3-dimensional core geometry using polynomial nodal method [8]. The NODAL3 code has been validated with static and transient benchmark problems and the calculated results give excellent agreement with the reference results $[8,9]$. In the NEACRP transient benchmark problems, there are 6 (six) benchmark problem cases, namely A1, $\mathrm{A} 2, \mathrm{~B} 1, \mathrm{~B} 2, \mathrm{C} 1$ and $\mathrm{C} 2$ cases [10]. The validation of NODAL3 code for A1, A2, B1 and B2 cases have been carried out using a quarter core geometry model since the ejection position of the control rod assemblies (CRs) can be symmetrically modeled either by half, quarter or octant core geometry model [11]. However, the NODAL3 code has not yet verified for $\mathrm{C} 1$ and $\mathrm{C} 2$ benchmark cases since the location of one CR ejection is at core periphery, which demands a full core geometry model.

The $\mathrm{C} 1$ and $\mathrm{C} 2$ cases are a $\mathrm{CR}$ ejection at peripheral core for hot zero power and full power conditions, respectively [9]. For the nodal code validation, the $\mathrm{C} 1$ and $\mathrm{C} 2$ cases are more challenging because the inserted reactivity is relatively high and the core calculation requires a full core geometry model. We also expect a severe change in the neutron flux distribution during the control rod ejection. The accuracy of polynomial nodal method (PNM) in the NODAL3 code can be evaluated in discretization the space variables of the full core geometry model of these $\mathrm{C}$ cases, especially near the peripheral area. By using a full core geometry model, the accuracies of boundary condition, convergence of iteration process and computation time of NODAL3 code can be thoroughly investigated. In other words, the objective of the present work is to validate the NODAL3 code against transients involving a CR ejection at a peripheral core using a full core geometry model. It is expected that the results of the present work will provide information on the accuracy of NODAL3 code, and complete the whole validation process.

The benchmarked transient parameters of $\mathrm{C}$ cases will be calculated by using adiabatic model (AM) and improved quasi-static model (IQSM) available in NODAL3 code. The calculated transient parameters by using NODAL3 code, such as maximum fuel temperature, time of power peak and final coolant temperature, will be compared with the reference solution results of the PANTHER code, which have been published in 1993 [1,11]. Beside the transient parameters, the boron concentration at criticality (static) parameter is also calculated. This research work is one important step before carrying out the validation of NODAL3 code against the PWR benchmark on uncontrolled rods withdrawal at zero power.

\section{BENCHMARK PROBLEMS}

The $\mathrm{C} 1$ and $\mathrm{C} 2$ cases in the NEACRP PWR core transient benchmark problem are a control rod ejection problem at the hot zero power (HZP) and the hot full power (HFP) conditions, respectively [10]. The core is operated by normal (initial) power of $2,775 \mathrm{MW}$ (thermal) with 157 fuel assemblies and 64 reflector elements $(21.606 \mathrm{~cm}$ in width in each direction). There are 49 control rod fuel assemblies (CR) in the core. The core configuration of $\mathrm{C}$ cases is depicted in Fig. 1.

Figure 1 shows that the number of type 1 and 2 CRs (CR1 and CR2) are 17 and 32, respectively, as well as the control rod position to be ejected. Under this core configuration, these $\mathrm{C}$ cases have to be solved using a full core geometry model. The single control rod ejection will generate a severe local power peak especially at the fuel assemblies adjacent to the reflector element. 
Table 1 shows the data and definition of the CR1 and CR2 assemblies. The initial position of control rod to be ejected is $37.7 \mathrm{~cm}$ ( 0 in unit of steps) for $\mathrm{C} 1$ case and $197.122 \mathrm{~cm}$ (100 in unit of steps) for C2 case. We noted that the fully inserted and fully withdrawn of the CR1 and CR2 assemblies correspond to 0 and 228 in unit of steps, respectively.
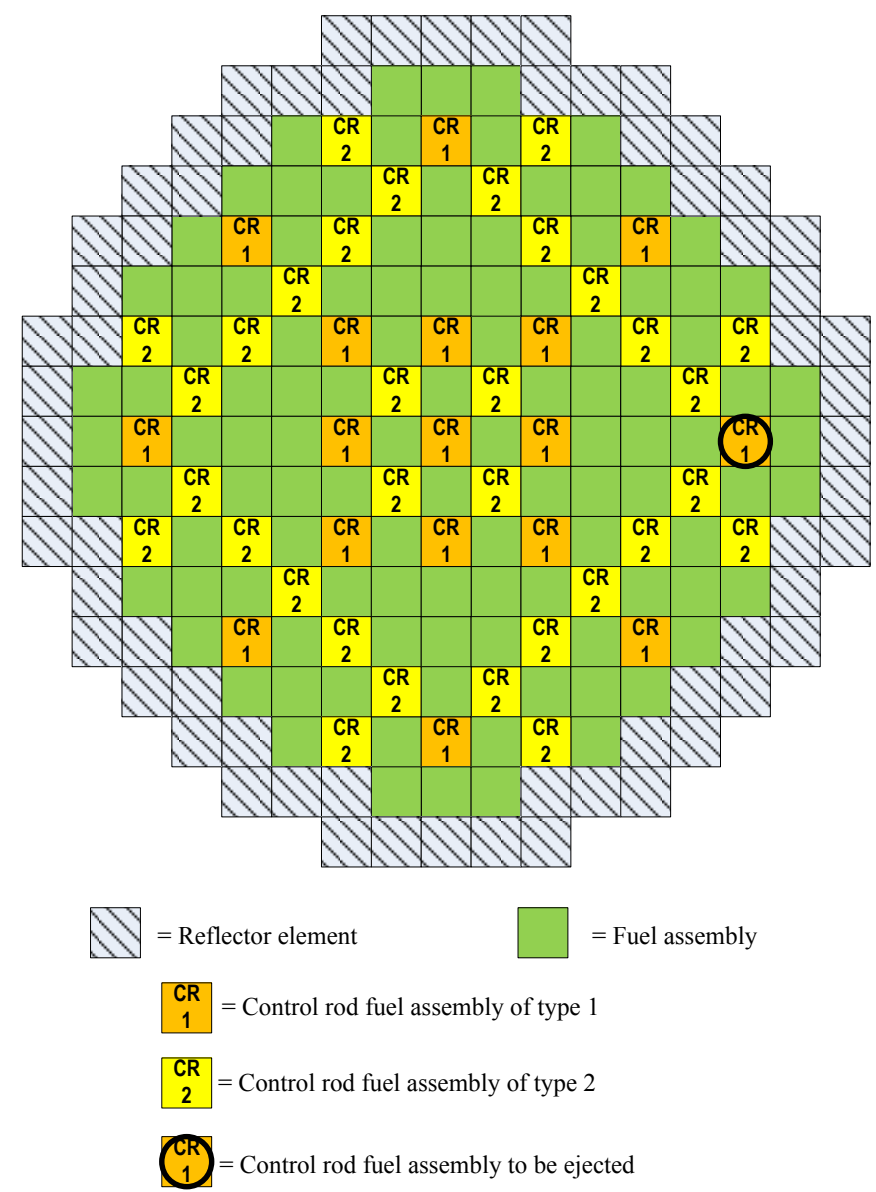

Figure 1. PWR NEACRP benchmark core configuration of C cases [10].

Tabel 1. Control rod fuel assembly (CR) data for $\mathrm{C} 1$ and $\mathrm{C} 2$ cases.

\begin{tabular}{|c|c|c|c|c|c|c|c|}
\hline \multirow{3}{*}{ Case } & \multirow{3}{*}{ Core Condition } & \multicolumn{3}{|c|}{ CR1 Assembly } & \multicolumn{3}{|c|}{ CR2 Assembly } \\
\hline & & \multirow[b]{2}{*}{ Number } & \multicolumn{2}{|c|}{ Initial position } & \multirow[b]{2}{*}{ Number } & \multicolumn{2}{|c|}{ Initial position } \\
\hline & & & $\begin{array}{c}\text { Unit of } \\
\text { step }\end{array}$ & Unit of $\mathrm{cm}$ & & $\begin{array}{c}\text { Unit of } \\
\text { step }\end{array}$ & Unit of $\mathrm{cm}$ \\
\hline $\mathrm{C} 1$ & $\begin{array}{c}\text { Hot zero power } \\
\text { (HZP) }\end{array}$ & 17 & 0 & 37.7 & 32 & 228 & 401.183 \\
\hline $\mathrm{C} 2$ & $\begin{array}{l}\text { Hot full power } \\
\text { (HFP) }\end{array}$ & 17 & 100 & 197.122 & 32 & 200 & 356.545 \\
\hline
\end{tabular}

\section{CALCULATION METHOD}

As specified in the Ref. [10], the core parameters, which should be calculated by the NODAL3 code, are as follows:

a. static parameters: critical boron concentration and maximum power peaking factor

b. transient parameters: time of power maximum, power maximum, final power (at $5 \mathrm{~s}$ ), final core averaged Doppler temperature (at $5 \mathrm{~s}$ ), maximum fuel centreline temperature and final coolant outlet temperature. 
All calculations were carried out by the adiabatic method (AM) and improved quasistatic method (IQM), which are adopted in the NODAL3 code [5]. The core configuration is modeled by 3 -dimension of (X-Y-Z) geometry with $2 \times 2 \times 1$ nodes for one assembly per layer. All calculations were carried out by time steps of $5 \mathrm{~ms}$. All T/H parameters in the NODAL3 code, such as heat conductivity and specific heat capacity, were taken from the benchmark case in Ref. [10] as well as the neutronic and kinetic parameters. This has been done to minimize the input data differences effect on the accuracy of the NODAL3 code. For the present validation, all calculation results of NODAL3 code are compared with the reference results as described in Ref. [11].

\section{RESULTS AND DISCUSSION}

Table 2 shows the relative differences of the calculated parameters by the NODAL3 code compared with the reference results. For critical boron concentration, the maximum relative difference of $0.76 \%$ occurs in the $\mathrm{C} 2$ case while the relative difference at $\mathrm{C} 1$ case is $0.18 \%$. These results show a very good agreement since the results are equivalent to the deviations of $8.81 \mathrm{ppm}$ at $\mathrm{C} 2$ case $2 \mathrm{ppm}$ for $\mathrm{C} 1$ case. For the power peaking factor, the AM and IQM methods give also a very good agreement to the reference since the relative differences are quite small, those are $0.04 \%$ and $0.72 \%$ for $\mathrm{C} 1$ and $\mathrm{C} 2$ cases, respectively.

Tabel 2. The calculation results of NODAL3 code for $\mathrm{C} 1$ and $\mathrm{C} 2$ cases.

\begin{tabular}{|c|c|c|c|}
\hline Core Parameters & Reference [10] & $\mathrm{AM}$ & IQM \\
\hline \multicolumn{4}{|c|}{ C1 Case } \\
\hline Critical boron concentration, ppm & 1135.30 & $\begin{array}{l}1133.30 \\
(0.18 \%)^{*}\end{array}$ & $\begin{array}{l}1133.30 \\
(0.18 \%)\end{array}$ \\
\hline Power peaking factor & 2.187 & $\begin{array}{c}2.188 \\
(0.05 \%)\end{array}$ & $\begin{array}{c}2.188 \\
(0.05 \%)\end{array}$ \\
\hline Time of power maximum, $\mathrm{s}$ & 0.270 & $\begin{array}{c}0.265 \\
(1.85 \%)\end{array}$ & $\begin{array}{l}0.270 \\
(0 \%)\end{array}$ \\
\hline Power maximum (P/2775 MW) & 4.773 & $\begin{array}{c}4.959 \\
(3.90 \%)\end{array}$ & $\begin{array}{c}4.860 \\
(1.82 \%)\end{array}$ \\
\hline Final power $(\mathrm{P} / 2775 \mathrm{MW})$ & 0.146 & $\begin{array}{c}0.142 \\
(2.74 \%)\end{array}$ & $\begin{array}{c}0.142 \\
(2.74 \%)\end{array}$ \\
\hline Averaged Doppler temperature at $5 \mathrm{~s},{ }^{\circ} \mathrm{C}$ & 315.900 & $\begin{array}{l}315.875 \\
(0.01 \%)\end{array}$ & $\begin{array}{l}315.787 \\
(0.04 \%)\end{array}$ \\
\hline Maximum fuel centreline temperature at $5 \mathrm{~s},{ }^{\circ} \mathrm{C}$ & 676.10 & $\begin{array}{l}672.240 \\
(0.57 \%)\end{array}$ & $\begin{array}{l}671.155 \\
(0.73 \%)\end{array}$ \\
\hline Final coolant outlet temperature at $5 \mathrm{~s},{ }^{\circ} \mathrm{C}$ & 291.500 & $\begin{array}{l}308.922 \\
(5.98 \%)\end{array}$ & $\begin{array}{l}308.872 \\
(5.96 \%)\end{array}$ \\
\hline \multicolumn{4}{|c|}{ C2 Case } \\
\hline Critical boron concentration, ppm & 1160.60 & $\begin{array}{l}1151.79 \\
(0.76 \%)\end{array}$ & $\begin{array}{l}1151.79 \\
(0.76 \%)\end{array}$ \\
\hline Power peaking factor & 2.221 & $\begin{array}{c}2.237 \\
(0.72 \%)\end{array}$ & $\begin{array}{c}2.237 \\
(0.72 \%)\end{array}$ \\
\hline Time of power maximum, $\mathrm{s}$ & 0.100 & $\begin{array}{c}0.096 \\
(4.00 \%)\end{array}$ & $\begin{array}{c}0.084 \\
(16.00 \%)\end{array}$ \\
\hline Power maximum (P/2775 MW) & 1.071 & $\begin{array}{c}1.148 \\
(7.19 \%)\end{array}$ & $\begin{array}{c}1.149 \\
(7.28 \%)\end{array}$ \\
\hline Final power $(\mathrm{P} / 2775 \mathrm{MW})$ & 1.030 & $\begin{array}{c}1.058 \\
(2.72 \%)\end{array}$ & $\begin{array}{c}1.058 \\
(2.72 \%)\end{array}$ \\
\hline Averaged Doppler temperature at $5 \mathrm{~s},{ }^{\circ} \mathrm{C}$ & 553.500 & $\begin{array}{l}562.365 \\
(1.60 \%)\end{array}$ & $\begin{array}{l}562.363 \\
(1.60 \%)\end{array}$ \\
\hline Maximum fuel centreline temperature at $5 \mathrm{~s},{ }^{\circ} \mathrm{C}$ & 1733.50 & $\begin{array}{l}1755.64 \\
(1.28 \%)\end{array}$ & $\begin{array}{l}1755.66 \\
(1.28 \%)\end{array}$ \\
\hline Final coolant outlet temperature at $5 \mathrm{~s},{ }^{\circ} \mathrm{C}$ & 324.500 & $\begin{array}{l}337.270 \\
(3.94 \%)\end{array}$ & $\begin{array}{l}337.276 \\
(3.94 \%)\end{array}$ \\
\hline
\end{tabular}

Note: *) all values in brackets are relative difference 
As can be observed from Table 2 and Figures 2-3, for the time of power maximum, the maximum relative difference of $16 \%$ occurs in the $\mathrm{C} 2$ case when using the IQM method. The maximum relative difference is equivalent to the $\Delta t$ (time) $=0.016 \mathrm{~s}$ or equal to 3 times of time step. On the other hand, in the $\mathrm{C} 1$ case, the AM method gives a relative difference of $1.85 \%$ which is equivalent to $\Delta t=0.005 \mathrm{~s}$ (same as one time step). The relative difference is decreased for the final power at $5 \mathrm{~s}$ in the range of $2.72 \%-2.74 \%$. The time of power maximum does not depend on the power maximum and the final power parameters, so their relative differences are not directly comparable. Regarding this issue, sensitivity analyses, especially the interval of time step, are needed to clarify the cause of the difference on the time of power maximum parameter.

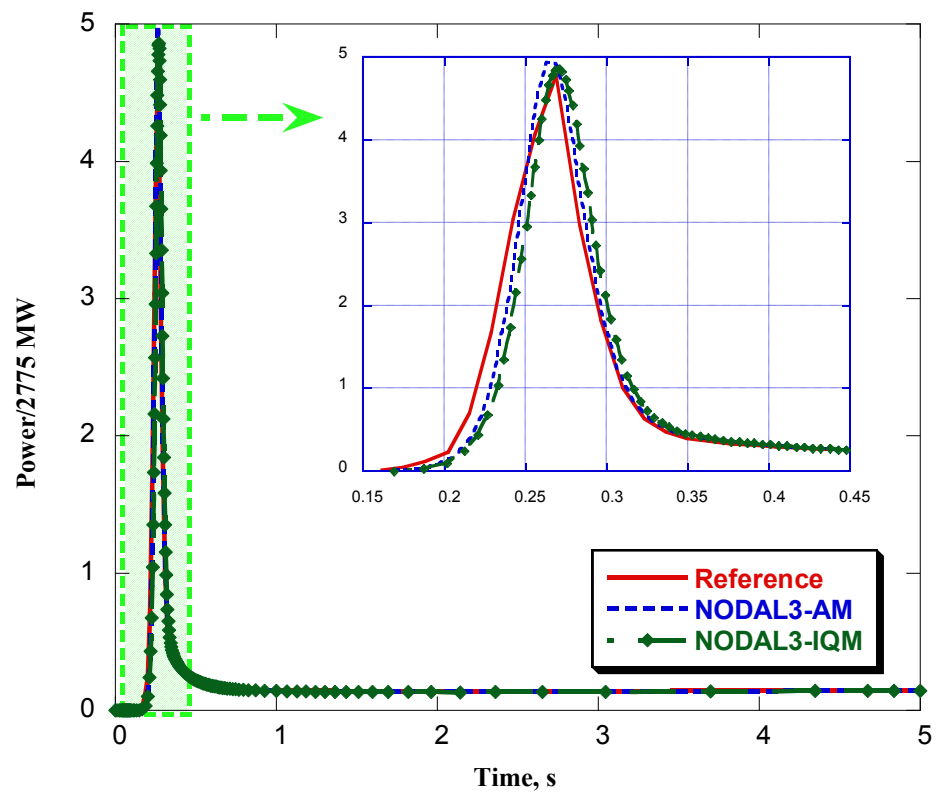

Figure 2. The power transient during $5 \mathrm{~s}$ after CE1 rod ejection (C1 Case).

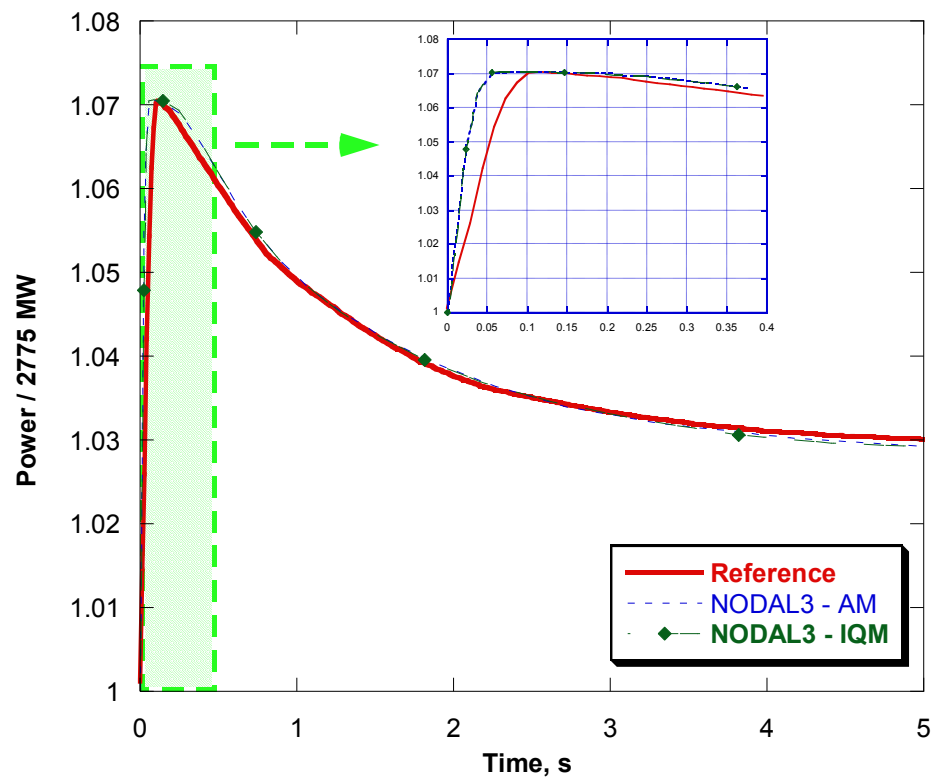

Figure 3. The power transient during $5 \mathrm{~s}$ after $\mathrm{CE} 1$ rod ejection (C2 case). 
The relative differences of the averaged Doppler temperature and the maximum centreline fuel temperature for the two cases are in the range of $0.01 \%-1.60 \%$, as seen in Table 2 and Figures 4-5. All calculated results by the NODAL3 code are slightly higher compared with the reference results, since the calculated power maximum and final power parameters by NODAL3 code are higher, too. The relative differences are equivalent to the range of $\Delta \mathrm{T}$ (temperature) of $0.025^{\circ} \mathrm{C}$ $22.140{ }^{\circ} \mathrm{C}$, so the NODAL3 code results agree very well with the reference results for these parameters.

The last transient parameter that should be compared is the final coolant outlet temperature (at $5 \mathrm{~s}$ ). Table 2 shows that the maximum relative difference of $5.98 \%$ occurs in the $\mathrm{C} 1$ case when using the $\mathrm{AM}$ method. This maximum difference is equivalent to $\Delta \mathrm{T}=17.422{ }^{\circ} \mathrm{C}$, while the minimum relative difference is equivalent to the $\Delta \mathrm{T}=12.770{ }^{\circ} \mathrm{C}$. The final coolant temperatures of the NODAL 3 code are higher than reference results, since the calculated power peaking and final power by the NODAL3 code are also higher. This indicates that the T/H module in the NODAL3 code gives a consistent result, since the final coolant temperature is a measure of the energy transfer from the fuel to the coolant, which is proportional to the time integral of the fission power. The accuracy of $\mathrm{T} / \mathrm{H}$ module also is affected by the steam table used and it is not clear whether the steam table we used is identical with the one used for the reference solutions.

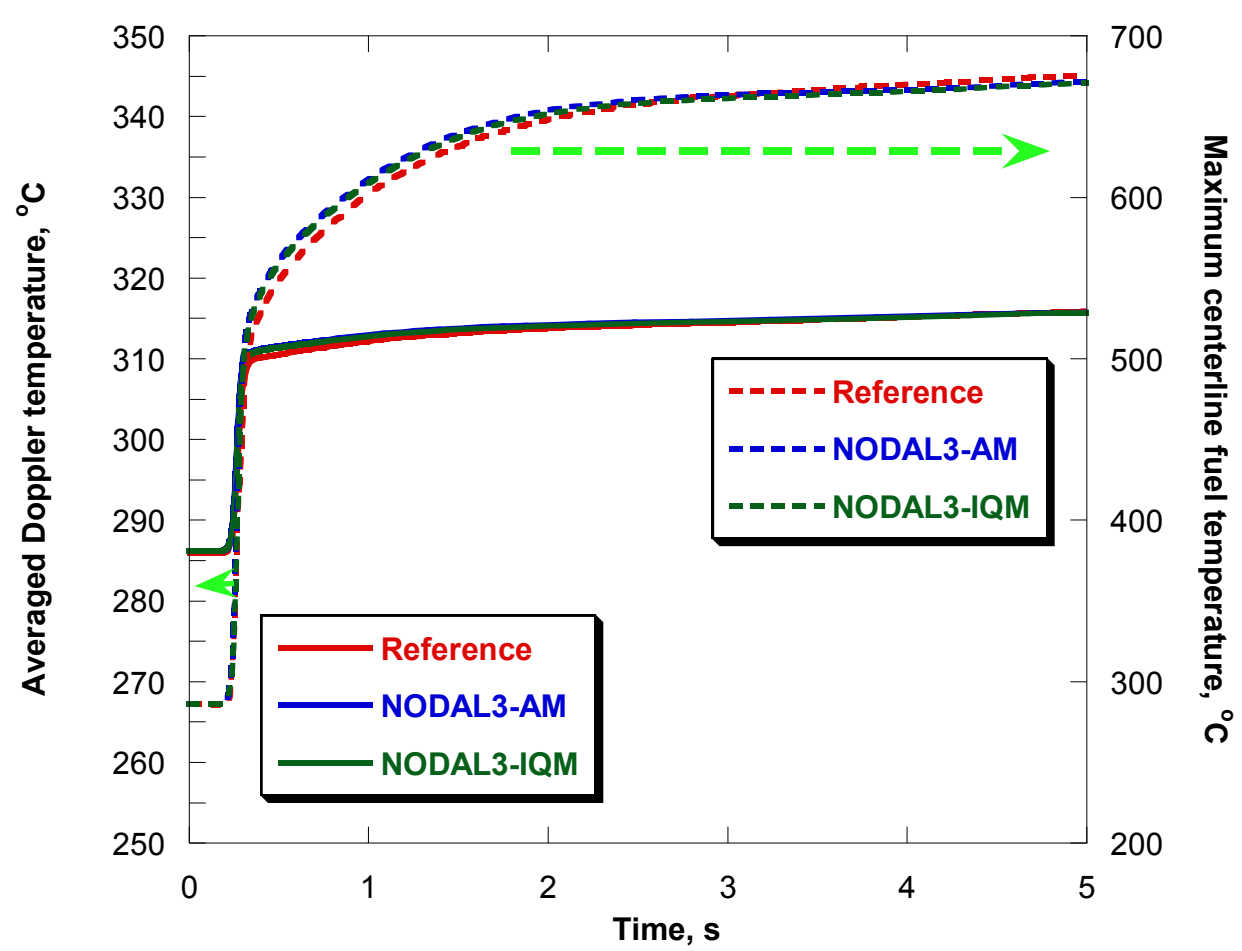

Figure 4. The calculated averaged Doppler and maximum centreline fuel temperatures for C1 case. 


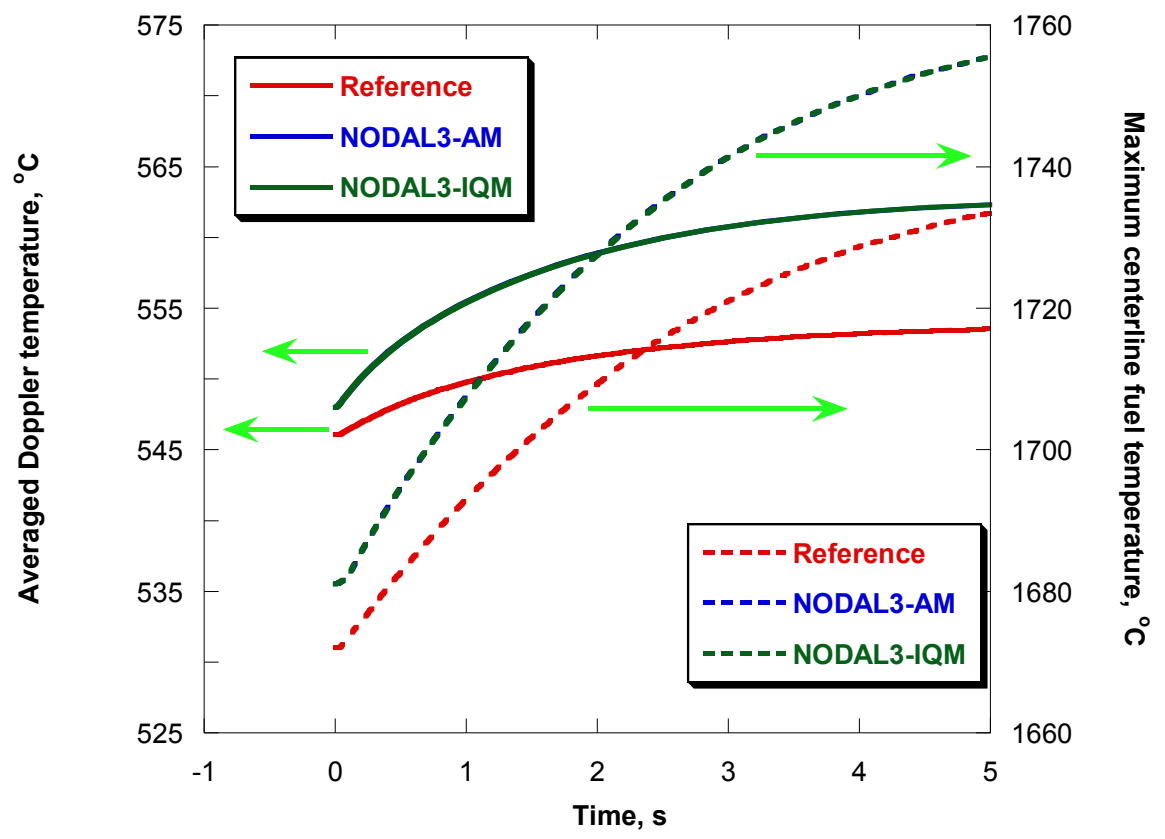

Figure 5. The calculated averaged Doppler and maximum centreline fuel temperatures for C2 case.

Furthermore, based on our previous work [8] including the present work, all calculation results by the NODAL3 code for 6 cases in the NEACRP benchmark shows no systematic relative differences, which means the neutronic and $\mathrm{T} / \mathrm{H}$ modules adopted in the NODAL3 code do not contain a systematic bug.

\section{CONCLUSIONS}

The calculated benchmark parameters of the NODAL3 code agree very well with the reference results for $\mathrm{C} 1$ and $\mathrm{C} 2$ cases of the PWR NEACRP transient benchmark problem which demanded a full core geometry modeling. The full core geometry model combined with severe local power peak due to peripheral control rod ejection does not show a lower accuracy compared with the previous results of $1 / 2$ core geometry model [8]. We also found no systematic relative differences in the benchmarked parameters compared with the reference solutions which indicated that no systematic bug in the T/H module of the NODAL3 code. Completing this work, the NODAL3 code is ready to be validated against other PWR transient benchmark cases such as the NEACRP uncontrolled rod withdrawal in the future. Furthermore, to clarify the cause of the difference on the time of power maximum parameter, the sensitivity analysis for this benchmark cases should be carried out.

\section{REFERENCES}

[1] Aoki S, Suemura T, Ogawa J, Takeda T. The Verification of 3 Dimensional Nodal Kinetics Code ANCK Using Transient Benchmark Problems. 2007;44(6):862-8.

[2] Jiménez J, Cuervo D, Aragonés JM. A domain decomposition methodology for pin by pin coupled neutronic and thermal - hydraulic analyses in COBAYA3. Nucl. Eng. Design 2010;240:313-20.

[3] Barrachina T, Garcia-fenoll M, Ánchel F, Miró R, Verdú G, Pereira C, et al. REA 3Ddynamic analysis in Almaraz NPP with RELAP5 / PARCS v2.7 and SIMTAB cross-sections tables. Prog. Nucl. Energy 2011;53(8):1167-80. 
[4] Aghaie M, Zolfaghari A, Minuchehr A. Coupled neutronic thermal - hydraulic transient analysis of accidents in PWRs. Ann. Nucl. Energy 2012;50:158-66.

[5] Grgic D, Bencik V, Sadek S. Coupled code calculation of rod withdrawal at power accident. Nucl. Eng. Design 2013;261:285-305.

[6] Lianjie W, Wenbo Z, Bingde C, Dong Y, Ping Y. Development of three dimensional transient analysis code STTA for SCWR core. Ann. Nucl. Energy 2015;78:26-32.

[7] Calleja M, Jimenez J, Sanchez V, Imke U, Stieglitz R, Macián R. Investigations of boron transport in a PWR core with COBAYA3/SUBCHANFLOW inside the NURESIM platform. Ann. Nucl. Energy 2014;66:74-84.

[8] Pinem S, Sembiring TM, Liem PH. The Verification of Coupled Neutronics ThermalHydraulics Code NODAL3 in the PWR Rod Ejection Benchmark. Science and Technology of Nuclear Installations 2014; 2014.

[9] Sembiring T.M, Pinem S. The validation of the NODAL3 code for static cases of the PWR benchmark core. Journal of Nuclear Science and Technology GANENDRA 2012;15:82-92.

[10] Finnemann H, Galati A. Paris: NEACRP 3-D LWR core transient benchmark-final specifications. OECD Nuclear Energy Agency; 1992 Jan. 75 p. NEACRP-L-335 (Revision 1).

[11] Finnemann H, Bauer H, Galati A, Martinelli R. Paris: Results of LWR core transient benchmarks. OECD Nuclear Energy Agency; 1993 Oct. 80 p. NEA/NSC/ DOC(93)25. 